Click www.researchjournal.co.in/online/subdetail.html to purchase.

Volume 5 | Issue 2 | September, 2014 | 179-183 — e ISSN-2231-6434 |

International Research Journal of Agricultural Economics and Statistics

Visit Us - www.researchjournal.co.in DOI : 10.15740/HAS/RJAES/5.2/179-183

\title{
Research Paper Economics of grape production in Marathwada region of Maharashtra state
}

\section{S.H. KAMBLE, R.A. KOLAMBKAR, R.V. CHAVAN AND S.P. PATIL}

See end of the paper for authors' affiliations

Correspondence to :

R.A. KOLAMBKAR

Department of

Agricultural Economics,

College of Agriculture,

Vasantrao Naik

Marathwada Krishi

Vidyapeeth, PARBHANI

(M.S.) INDIA

Email:

kolambkar.rachana14@gmail.

com

Paper History :

Received : 01.05 .2014

Revised : 00.00.2014;

Accepted: 00.00 .2014
ABSTRACT : Present study was undertaken for the year 2011-2012. The popular varieties of grape cultivated by sample growers were Thompson seedless, Tas-A-Ganesh, Sonaka, Manik -chaman, Sharad seedless, and Cheemasahebi, out of which share of Thompson seedless variety was 60 per cent. The per hectare establishment cost of grape orchard was Rs. 3,55,520 out of which maximum expenditure was made on plantation. Regarding the profitability, grape cultivation was profitable at all cost levels. Benefit-cost ratio at cost A, cost B and cost $\mathrm{C}$ were $2.45,1.46$ and 1.31 , respectively. Financial feasibility analysis showed that, NPW of the project was 2558845, BCR was 2.37 and IRR 149.37 per cent, which indicated investment made in grape production was financially highly feasible. The problem faced by sample cultivators in grape production were non-availability of labour in time, followed by non-availability of fertilizers, credit and pesticides reported by 100, 94, 90, 74 per cent growers, respectively.

KEY WORDS : Grape, Economics, Production, Feasibility

HOW TO CITE THIS PAPER : Kamble, S.H., Kolambkar, R.A., Chavan, R.V. and Patil, S.P. (2014). Economics of grape production in Marathwada region of Maharashtra state. Internat. Res. J. Agric. Eco. \& Stat., 5 (2) : 179-183. 